\title{
Factors predisposing to adjacent 2 and $3: 1$ disjunctions: study of 161 human reciprocal translocations
}

\author{
P. JALBERT AND B. SELE
}

From the Laboratoire de Cytogénétique du CHU de Grenoble, Hôpital des Sablons, F 38700

La Tronche, France

SUMMARY Reciprocal translocations produce imbalances by three types of disjunction which are, in decreasing frequency, adjacent $1,3: 1$, and adjacent 2 .

Adjacent 1 disjunction produces duplication deficiencies of inverse topography to those of adjacent 2. The imbalanced chromosome segments in one of these types are balanced in the other. The disjunction $3: 1$ produces pure trisomies and monosomies.

The following situations predispose to adjacent 2 disjunction: translocations between the long arms of two acrocentric chromosomes or between one of these and that of a No 9 chromosome; centric segments, either short or carrying a heterochromatic zone (9qh); a balanced translocation in the mother.

The factors predisposing to the disjunction adjacent 2 operate by selection, or directly on the meiotic configuration. Some of them (shortness of the interstitial segment, shortness of the short arms of translocation chromosomes) act in both these ways. Their influence is probably responsible for the repetitive and exclusive character of this disjunction.

The conditions for the occurrence of the 3:1 disjunctions seem less strict than those for adjacent 2, although they should be of the same nature (involvement of acrocentrics or a chromosome 9 in the translocation, maternal origin).

Imbalances of reciprocal translocations can result from three types of disjunction.

Type adjacent 1 (the most frequent) occurs when one of the two modified chromosomes is transmitted together with the normal homologue of the other. This situation results in the duplication of one of the translocated segments and the deficiency of the other.

Type adjacent 2 (exceptional) occurs when one of the modified chromosomes is transmitted together with its own homologue. This mechanism results in the duplication deficiency of the non-translocated centric segments of the modified chromosomes; the translocated acentric segments are therefore balanced.

The offspring of the above types of disjunction have $\mathbf{4 6}$ chromosomes.

Type 3:1 (rare) results in pure partial monosomies or trisomies. The subjects have 45 to 47 chromosomes.

Received for publication 7 February 1979
Two mechanisms are possible.

(1) The two chromosomes affected by the translocation are transmitted together with only one of their normal homologues ('interchange trisomy or monosomy').

(2) A single affected chromosome is transmitted together with the two normal homologues ('tertiary trisomy or monosomy').

The incidence and the mechanisms bringing about these different types of chromosome imbalance have already been reviewed by Ford and Clegg (1969), Lejeune et al. (1970), Hamerton (1971), and Lindenbaum and Bobrow (1975).

The observation that two members of a family were born with the same type adjacent 2 constitution led us to investigate published reports regarding this phenomenon and to study the mechanisms involved. Data concerning 3:1 disjunction previously established by Lindenbaum and Bobrow (1975) are relevant to the present study. 


\section{Case report}

The proband is the third child of the family; the two elder sisters, identical twins (Fig. 1), are normal. There had been no previous miscarriages. A maternal uncle is mentally retarded. At the time of the child's birth the mother was aged 24 years and the father 27 . Weight at birth (full term) was $2510 \mathrm{~g}$.

At 9 months, examination of the infant showed evidence of hypotrophy, retarded mental development, and a dysmorphic syndrome characteristic of a $9 p$ trisomy.

There was a chromosome anomaly derived from a balanced reciprocal translocation in the mother and the maternal grandmother $\mathrm{t}(9 ; 21)$ (q22;q22) (Fig. 2a). The child's karyotype was: $46, X X,-21,+\operatorname{der}(9)$,

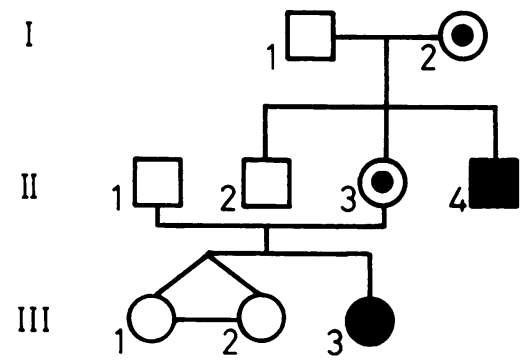

Fig. 1 Pedigree of the family. I.2 and II.3 are $46, X X, t(9 ; 21)(q 22 ; q 22), I I .4$ and III.3 are $46,-21,+\operatorname{der}(9) t(9 ; 21)(q 22 ; q 22)(9 p$ trisomy).

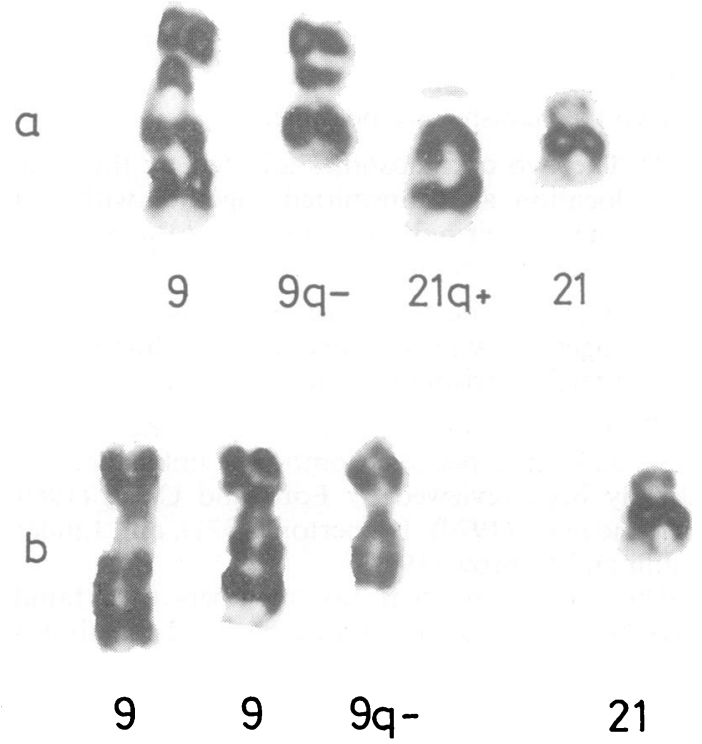

Fig. 2 Partial karyotypes of the proband (b) and her mother (a).

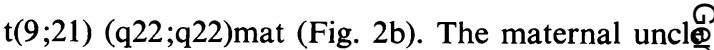
(case II.4) has the same imbalance.

These two subjects have received from their. mother the chromosome $9 q-$, as well as the norma chromosome 9, but neither of the two chromosomes 21. They are therefore trisomic for the centrio portion of chromosome 9 and monosomic for thase of 21.

The twin sisters and the father of the patient have normal karyotypes.

\section{Materials and methods}

A study was carried out on 161 families wit reciprocal translocations with an abnormal proband (158 came from published reports of the last 5 years? 3 originate from this laboratory). These families contain 221 imbalanced subjects. The translocate chromosomes and the breakpoints were identified by banding techniques.

The sample was divided into 2 groups.

Group I: translocations involving at least on acrocentric chromosome (reciprocal translocations between two acrocentrics or between one acrocentrig and one non-acrocentric): 98 families (Table 1).

Group II: translocations involving no acrocentrico 63 families (Table 2).

The subjects of the two groups were listed accordo ing to the precise origin of their chromosome cin stitution: alternate, adjacent 1 , adjacent 2 , or $3: \vec{\Gamma}$.

The paternal or maternal origin of the disjunction was noted. Spontaneous abortions and stillbirth were not listed unless their karyotype was known.

\section{Results}

The resulting imbalances in decreasing order o frequency were disjunctions adjacent $1(66.5 \%$ $3 \cdot 2 \%), 3: 1(27 \cdot 6 \% \pm 3 \cdot 0 \%)$, and adjacent $2(5 \cdot 9 \%$ $\pm 1 \cdot 6 \%$ ). The last type was only found 13 times in families (Table 3).

\section{ADJACENT 2 DISJUNCTIONS}

These were all found in group I (Table 4) and never in group $\Pi$ (Table 5). These translocations always occur between the long arms of two acrocentrics or between that of an acrocentric and that of a chromos some 9 (Table 6). Any acrocentric can be involvedo the sample size is too small to evaluate randomnes\$

However, there have been reported (Raoul et al 1976; Kim et al., 1977) two translocations not affected by adjacent 2 segregation, though involving two long arms of acrocentrics (the interstitial sege ments are in these cases particularly long). Similarly 15 translocations have taken place between a No 8 
Table 1 Translocations involving at least one acrocentric chromosome

\begin{tabular}{|c|c|c|c|c|c|c|}
\hline Authors & Chromosomes & Altern & Adj 1 & Adj 2 & $3: 1$ & Proband \\
\hline A buello et al. (1977) & $(8 ; 13)(\mathrm{q} 21 ; \mathrm{q} 34) \mathrm{mat}$ & & 1 & & & trisomy $\mathbf{8 q}$ \\
\hline Alfi et al. (1973) & $(7 ; 14)$ (q31;qter)pat & & 1 & & & trisomy $7 q$ \\
\hline Archidiacono et al. (1978) & $(9 ; 22)($ cen;p11)mat & & 1 & & & trisomy 9p \\
\hline Armendares et al. (1975) & $(12 ; 21)(\mathrm{p} 11 ; \mathrm{p} 11) \mathrm{mat}$ & 4 & 1 & & & trisomy $12 p$ \\
\hline \multirow{2}{*}{\multicolumn{7}{|c|}{$\begin{array}{l}\text { Armendares and Salamanca-Gomez } \\
\text { (1978) }\end{array}$}} \\
\hline & $(2 ; 15)(\mathrm{p} 21 ; \mathrm{q} 26)$ pat & & 2 & & & trisomy $2 p$ \\
\hline Aurias et al. (1975) & $(11 ; 22)(\mathrm{q} 231 ; \mathrm{q} 111) \mathrm{mat}$ & 6 & & & 1 & trisomy $11 \mathrm{q}$ \\
\hline Ayraud et al. (1976) & $(11 ; 22)(q 231 ; q 111)$ mat & 3 & & & 1 & trisomy $11 \mathrm{q}$ \\
\hline Baccichetti et al. (1975) & $\begin{array}{l}(11 ; 22)(q 231 ; q 111) \text { mat } \\
(4 ; 21)(q 32 ; q 22) \text { mat }\end{array}$ & $\begin{array}{l}2 \\
2\end{array}$ & 1 & & 1 & trisomy $11 \mathrm{q}$ \\
\hline Balicek et al. (1975) & $(9 ; 15)(\mathrm{q} 12 ; \mathrm{p} 11) \mathrm{mat}$ & 4 & & & 1 & trisomy $9 p$ \\
\hline Bass et al. (1978) & $(5 ; 14)(\mathrm{p} 11 ; \mathrm{q} 11) \mathrm{mat}$ & & & & 1 & monosomy $5 p$ \\
\hline Bergamo et al. (1977) & $(9 ; 15)(\mathrm{p} 22 ; \mathrm{q} 11) \mathrm{mat}$ & 1 & & & 1 & monosomy $9 p$ \\
\hline Biederman et al. (1977) & $(12 ; 21)(\mathrm{p} 11 ;$ pter $)$ pat & & 1 & & & trisomy $12 p$ \\
\hline Blank et al. (1975) & $(9 ; 22)(\mathrm{q} 13 ; \mathrm{q} 11) \mathrm{mat}$ & 11 & & 4 & & trisomy $9 p$ \\
\hline Borgaonkar et al. (1973) & $(17 ; 22)(\mathrm{p} 1 ; \mathrm{q} 1) \mathrm{mat}$ & & & & 1 & trisomy $22 q$ \\
\hline Brimblecombe et al. (1977) & $(5 ; 15)(\mathrm{p} 11 ; \mathrm{p} 12) \mathrm{mat}$ & 33 & 1 & & & trisomy 5p \\
\hline Cantu et al. (1975) & $(10 ; 21)(\mathrm{p} 11 ; \mathrm{p} 11) \mathrm{mat}$ & 2 & 2 & & & trisomy $10 p$ \\
\hline Castel et al. (1976) & $(7 ; 15)(q 35 ; q 14)$ mat & 1 & & & 1 & trisomy $15 q$ \\
\hline Centerwall et al. (1976) & $(9 ; 14)(\mathrm{p} 22 ; \mathrm{q} 32) \mathrm{mat}$ & 4 & 6 & & & trisomy $9 p$ \\
\hline Centerwall and Francke (1977) & $(13 ; 20)(\mathrm{q} 34 ; \mathrm{p} 11.2) \mathrm{mat}$ & & 3 & & & trisomy $20 p$ \\
\hline Chaganti et al. (1976) & $(5 ; 21)(\mathrm{p} 11 ; \mathrm{q} 11) \mathrm{mat}$ & 2 & & & 1 & $\begin{array}{l}\text { monosomy } 5 p \\
\text { monosomy } 21 q\end{array}$ \\
\hline de la Chapelle et al. (1973) & $(4 ; 21)(\mathrm{q} 21 ; \mathrm{q} 21) \mathrm{mat}$ & 6 & & & 1 & trisomy $4 \mathrm{q}$ \\
\hline Chiyo et al. (1975) & $(8 ; 13)(\mathrm{p} 11 ; \mathrm{q} 34)$ pat & & 2 & & & trisomy $8 p$ \\
\hline Coco and Penchaszadeh (1977) & $(2 ; 14)(\mathrm{q} 12 ; \mathrm{q} 13)$ mat & 6 & & & 1 & trisomy $14 q$ \\
\hline Cohen et al. (1975a) & $(20 ; 22)(\mathrm{p} 11 ; \mathrm{q} 13)$ pat & 11 & 2 & & & trisomy $20 p$ \\
\hline Cohen et al. (1975b) & $(4 ; 15)(\mathrm{p} 16 ; \mathrm{q} 22) \mathrm{mat}$ & 3 & & & 2 & trisomy $15 q$ \\
\hline Dallapiccola et al. (1977) & $(4 ; 22)(\mathrm{p} 11 ; \mathrm{p} 12) \mathrm{mat}$ & 2 & 1 & & 1 & trisomy $4 p$ \\
\hline Darmady and Seabright (1975) & $(4 ; 21)(\mathrm{p} 11 ; \mathrm{p} 12) \mathrm{mat}$ & 1 & 1 & & & trisomy $4 p$ \\
\hline Forabosco et al. (1973) & $(2 ; 13)(q 32 ; q 33)$ mat & 1 & 1 & & & trisomy $2 \mathrm{q}$ \\
\hline Fried et al. (1977) & $(5 ; 14)(\mathrm{p} 15 ; \mathrm{q} 13) \mathrm{mat}$ & 3 & & & 1 & monosomy $5 p$ \\
\hline Fryns et al. (1977) & $(11 ; 14)(\mathrm{q} 25 ; \mathrm{q} 23) \mathrm{pat}$ & & 1 & & & trisomy $14 \mathrm{q}$ \\
\hline Fu et al. (1976) & $(11 ; 22)(\mathrm{q} 25 ; \mathrm{q} 11) \mathrm{mat}$ & 3 & & & & \\
\hline Garlinger et al. (1977) & $(4 ; 22)(\mathrm{p} 16 ; \mathrm{q} 12) \mathrm{mat}$ & 3 & & & 1 & trisomy $22 q$ \\
\hline Genest et al. (1977) & $(9 ; 22)(\mathrm{p} 11 ; \mathrm{p} 11)$ mat & 1 & 1 & & & trisomy $9 p$ \\
\hline Giovannelli et al. (1974) & $(4 ; 22)(\mathrm{p} 11 ; \mathrm{p} 12) \mathrm{mat}$ & & 2 & & & trisomy $4 p$ \\
\hline Giraud et al. (1977) & $(2 ; 13)(q 36 ; q 13) m a t$ & 1 & $\mathbf{1}$ & & & trisomy $13 q$ \\
\hline Habedank and Faust (1978) & $(9 ; 21)(\mathrm{p} 11 ; \mathrm{q} 11) \mathrm{mat}$ & 1 & & & 2 & trisomy $9 p$ \\
\hline Hansteen et al. (1978) & $(12 ; 21)(\mathrm{p} 12 ; \mathrm{p} 11) \mathrm{mat}$ & 3 & 2 & & 1 & $\begin{array}{l}\text { trisomy } 12 p \\
\text { trisomy } 21 q\end{array}$ \\
\hline Hobolth et al. (1974) & $(12 ; 21)(q 24 ; p 11) m a t$ & & 1 & & & trisomy $12 q$ \\
\hline Howard-Peebles et al. (1977) & $(9 ; 13)(q 22 ; q 12) m a t$ & 7 & & 1 & & trisomy $9 p$ \\
\hline Hustinx et al. (1974) & $(10 ; 14)($ cen;cen $) \mathrm{mat}$ & 1 & 1 & & & trisomy $10 p$ \\
\hline Hustinx et al. (1975) & $(4 ; 15)(\mathrm{p} 11 ; \mathrm{q} 11) \mathrm{mat}$ & 5 & & & 1 & trisomy $4 p$ \\
\hline Jenkins and Boyd (1976) & $(4 ; 21)(\mathrm{q} 27 ; \mathrm{p} 11) \mathrm{mat}$ & & & & 1 & trisomy 21 \\
\hline Jotterand and Juillard (1976) & $(9 ; 13)(\mathrm{p} 21 ; \mathrm{q} 21) \mathrm{mat}$ & 1 & 1 & & & trisomy $13 q$ \\
\hline Kajii et al. (1974) & $(13 ; 18)(\mathrm{q} 12 ; \mathrm{q} 21)$ pat & 1 & 1 & & 2 & \\
\hline Kessel and Pfeiffer (1977) & $(11 ; 22)(\mathrm{q} 23 ; \mathrm{q} 12) \mathrm{mat}$ & & & & 1 & trisomy 22 \\
\hline Kim et al. (1977) & $(13 ; 22)(\mathrm{q} 22 ; \mathrm{q} 12) \mathrm{mat}$ & & & & 1 & $\begin{array}{l}\text { trisomy } 13 q \\
\text { trisomy } 22 q\end{array}$ \\
\hline Lange and Alfi (1976) & $(19 ; 22)(\mathrm{q} 13 ; \mathrm{p} 13) \mathrm{mat}$ & 2 & 2 & & & trisomy $19 p$ \\
\hline Larson et al. (1977) & $(7 ; 22)(\mathrm{p} 21 ; \mathrm{q} 13)$ pat & 8 & 1 & & & trisomy $7 p$ \\
\hline Laurent et al. (1973) & $(14 ; 21)(\mathrm{q} 12 ; \mathrm{q} 22)$ pat & & & 1 & & trisomy $14 q$ \\
\hline Laurent et al. (1975a) & $(11 ; 22)(\mathrm{q} 231 ; \mathrm{q} 11) \mathrm{mat}$ & & & & 1 & trisomy $11 \mathrm{q}$ \\
\hline Mulcahy and Jenkyn (1975) & $(9 ; 21)(\mathrm{p} 13 ; \mathrm{q} 22) \mathrm{mat}$ & 1 & 1 & & & trisomy $9 p$ \\
\hline Nakagome and Kobayashi (1975) & $(10 ; 22)(\mathrm{p} 11 ; \mathrm{p} 11) \mathrm{mat}$ & 3 & 2 & & & trisomy $10 p$ \\
\hline Niazi et al. (1978) & $(18 ; 21)(\mathrm{q} 21 ; \mathrm{q} 22) \mathrm{mat}$ & 1 & 1 & & & trisomy $18 q$ \\
\hline Nielsen et al. (1976) & $(4 ; 13)(\mathrm{q} 25 ; \mathrm{q} 31) \mathrm{mat}$ & 2 & 2 & & & trisomy $4 q^{4}$ \\
\hline Noel et al. (1976a) & $(11 ; 22)(\mathrm{q} 231 ; \mathrm{q} 111) \mathrm{mat}$ & 4 & & & 1 & trisomy $11 \mathrm{q}$ \\
\hline Noel et al. (1976b) & $(13 ; 22)(\mathrm{q} 12 ; \mathrm{p} 11) \mathrm{mat}$ & & 1 & & 1 & trisomy $13 q$ \\
\hline Orye et al. (1975) & $\begin{array}{l}(5 ; 13)(\mathrm{p} 13 ; \mathrm{q} 14) \mathrm{mat} \\
(9 ; 15)(\mathrm{p} 22 ; \mathrm{q} 26) \mathrm{pat}\end{array}$ & & $\begin{array}{l}2 \\
1\end{array}$ & & & trisomy $13 q$ \\
\hline Owen et al. (1974) & $\begin{array}{l}(9 ; 15)(\mathrm{p} 22 ; \mathrm{q} 26) \text { pat } \\
(4 ; 21)(\mathrm{p} 14 ; \mathrm{p} 22) \text { pat }\end{array}$ & & 1 & & & monosomy 9p \\
\hline Pena et al. (1976) & $\begin{array}{l}(4 ; 21)(\mathrm{p} 14 ; \mathrm{p} 22) \mathrm{pat} \\
(13 ; 14)(\mathrm{q} 13 ; \mathrm{q} 22) \mathrm{mat}\end{array}$ & & & 2 & & $\begin{array}{l}\text { trisomy } 4 p \\
\text { trisomy } 14 q\end{array}$ \\
\hline Pfeiffer and Kessel (1976) & $(8 ; 15)(\mathrm{q} 24 ; \mathrm{q} 13) \mathrm{mat}$ & 3 & & & 2 & trisomy $15 q$ \\
\hline Pfeiffer et al. (1977) & $(19 ; 21)(\mathrm{p} 13 ; \mathrm{q} 21) \mathrm{mat}$ & 1 & 1 & & & trisomy $21 \mathrm{q}$ \\
\hline & $(4 ; 21)(\mathrm{q} 27 ; \mathrm{q} 21) \mathrm{mat}$ & & & & 1 & trisomy $4 \mathrm{q}$ \\
\hline Philippe et al. (1975) & $(9 ; 22)(\mathrm{p} 11 ; \mathrm{q} 11) \mathrm{mat}$ & 1 & & & 1 & trisomy $9 p$ \\
\hline Podruch and Weisskopf (1974) & $(9 ; 15)(\mathrm{q} 13 ; \mathrm{p} 11) \mathrm{mat}$ & 4 & & & 2 & trisomy $9 p$ \\
\hline Raoul et al. (1975) & $(10 ; 14)(\mathrm{p} 152 ; \mathrm{q} 22)$ mat & 2 & & & 1 & trisomy 14q \\
\hline Raoul et al. (1976) & $(15 ; 21)(q 262 ; q 21) m a t$ & 3 & 1 & & 1 & trisomy $21 \mathrm{q}$ \\
\hline Rethoré et al. (1973a) & $\begin{array}{l}(9 ; 22)(\mathrm{q} 13 ; \mathrm{q} 13) \text { mat } \\
(9 ; 22)(\mathrm{p} 12 ; \mathrm{p} 11) \text { pat }\end{array}$ & & & & $\begin{array}{l}1 \\
2\end{array}$ & $\begin{array}{l}\text { trisomy } 9 p \\
\text { trisomy } 9 p\end{array}$ \\
\hline
\end{tabular}


Table 1-continued

\begin{tabular}{|c|c|c|c|c|c|c|c|}
\hline Authors & Chromosomes & Altern & Adj 1 & Adj 2 & $3: 1$ & Proband & $\stackrel{\overline{\mathbb{D}}}{\longrightarrow}$ \\
\hline Rethoré et al. (1973b) & $(15 ; 21)(\mathrm{q} 13 ; \mathrm{q} 221) \mathrm{mat}$ & & & 2 & & $\begin{array}{l}\text { monosomy } 21 \mathrm{q} \\
\text { trisomy } 15 \mathrm{q}\end{array}$ & $\underset{\overrightarrow{\vec{\omega}}}{\overrightarrow{\vec{C}}}$ \\
\hline Rosenmann et al. (1978) & $(13 ; 18)(\mathrm{q} 32 ; \mathrm{q} 11)$ pat & 1 & 1 & & & trisomy $18 q$ & \\
\hline Roux et al. (1974) & $(10 ; 22)(\mathrm{q} 24 ; \mathrm{q} 12) \mathrm{mat}$ & 2 & 1 & & & trisomy $10 q$ & \\
\hline Sanchez et al. (1977) & $(20 ; 21)(\mathrm{q} 13 ; \mathrm{q} 214) \mathrm{mat}$ & & & & 1 & $\begin{array}{l}\text { trisomy } 20 \mathrm{q} \\
\text { trisomy } 21 \mathrm{q}\end{array}$ & $\frac{\bar{\sigma}}{\frac{1}{D}}$ \\
\hline Schrott et al. (1974) & $(4 ; 13)(\mathrm{q} 26 ; \mathrm{q} 34) \mathrm{mat}$ & 9 & 1 & & & trisomy $4 p$ & لِ \\
\hline Schrott et al. (1974) & $(4 ; 13)(\mathrm{q} 26 ; \mathrm{q} 34) \mathrm{mat}$ & 3 & 1 & & & trisomy $4 \mathrm{q}$ & \\
\hline Schwanitz and Grosse (1973) & $(4 ; 22)(\mathrm{p} 14 ; \mathrm{p} 11)$ pat & & 2 & & & trisomy $4 p$ & \\
\hline Schwanitz et al. (1977) & $(3 ; 22)(\mathrm{q} 25 ; \mathrm{p} 11) \mathrm{mat}$ & 2 & 2 & & & trisomy $3 q$ & \\
\hline Short et al. (1972) & $(9 ; 14)(\mathrm{p} 2 ; \mathrm{q} 24) \mathrm{mat}$ & 1 & & & 1 & trisomy $14 q$ & \\
\hline Simpson and Zellweger (1977) & $(3 ; 14)(\mathrm{q} 23 ; \mathrm{q} 21) \mathrm{mat}$ & 10 & & & 1 & trisomy $14 q$ & $\omega$ \\
\hline Stoll et al. (1974) & $(2 ; 15)(\mathrm{p} 22 ; \mathrm{p} 11) \mathrm{mat}$ & 1 & 2 & & & trisomy $2 p$ & \\
\hline Subrt et al. (1976) & $(9 ; 21)(\mathrm{q} 13 ; \mathrm{q} 11) \mathrm{mat}$ & & & 1 & & trisomy $9 p$ & 3 \\
\hline Surana et al. (1977) & $(3 ; 22)(\mathrm{p} 2 ; \mathrm{q} 13)$ pat & 1 & 1 & & & trisomy $3 p$ & $\vec{\theta}$ \\
\hline Turleau et al. (1975) & $(12 ; 14)(\mathrm{q} 244 ; \mathrm{q} 21) \mathrm{mat}$ & 3 & & & 1 & trisomy $14 \mathrm{q}$ & $\bar{c}$ \\
\hline Turleau and de Grouchy (1977) & $(14 ; 18)(\mathrm{p} 13 ; \mathrm{q} 21) \mathrm{mat}$ & & 1 & & & trisomy $18 \mathrm{q}$ & க் \\
\hline Turleau et al. (1977) & $(14 ; 18)(\mathrm{p} 12 ; \mathrm{q} 22) \mathrm{mat}$ & & 2 & & & $\begin{array}{l}\text { trisomy } 18 \mathrm{q} \\
\text { monosomy } 18 \mathrm{q}\end{array}$ & के \\
\hline Vogel et al. (1973) & $(7 ; 21)(q 31 ; p 13) m a t$ & & 1 & & & trisomy $7 q$ & \\
\hline Wilroy (1977) & $(13 ; 17)(\mathrm{q} 13 ; \mathrm{p} 13) \mathrm{mat}$ & 1 & 2 & & 1 & trisomy $13 q$ & \\
\hline Young et al. (1976) & $(14 ; 16)(\mathrm{q} 11 ; \mathrm{q} 24) \mathrm{mat}$ & & & & 1 & trisomy $14 q$ & \\
\hline Yunis et al. (1976) & $(10 ; 21)(\mathrm{p} 11 ; \mathrm{p} 11)$ pat & & 1 & & & trisomy $10 p$ & \\
\hline Yunis et al. (1977a) & $(15 ; 16)(p 12 ; q 11)$ pat & & & & 1 & trisomy $16 q$ & \\
\hline Yunis et al. (1977b) & $(4 ; 15)(\mathrm{q} 11 ; \mathrm{p} 11)$ pat & & 1 & & & trisomy $4 \mathrm{q}$ & לִ \\
\hline Zabel and Baumann (1977) & $(X ; 15)(\mathrm{p} 22 ; \mathrm{q} 15) \mathrm{mat}$ & & 1 & & & trisomy $15 q$ & 吕 \\
\hline Zabel et al. (1978) & $(5 ; 22)(\mathrm{q} 33 ; \mathrm{q} 13)$ pat & 2 & 1 & & & trisomy $5 q$ & $\frac{3}{\sigma}$ \\
\hline Present case No 73.276 & $(9 ; 21)(\mathrm{q} 22 ; \mathrm{q} 22)$ mat & 4 & & 2 & & trisomy $9 p$ & (D) \\
\hline
\end{tabular}

Table 2 Translocations involving no acrocentric chromosome

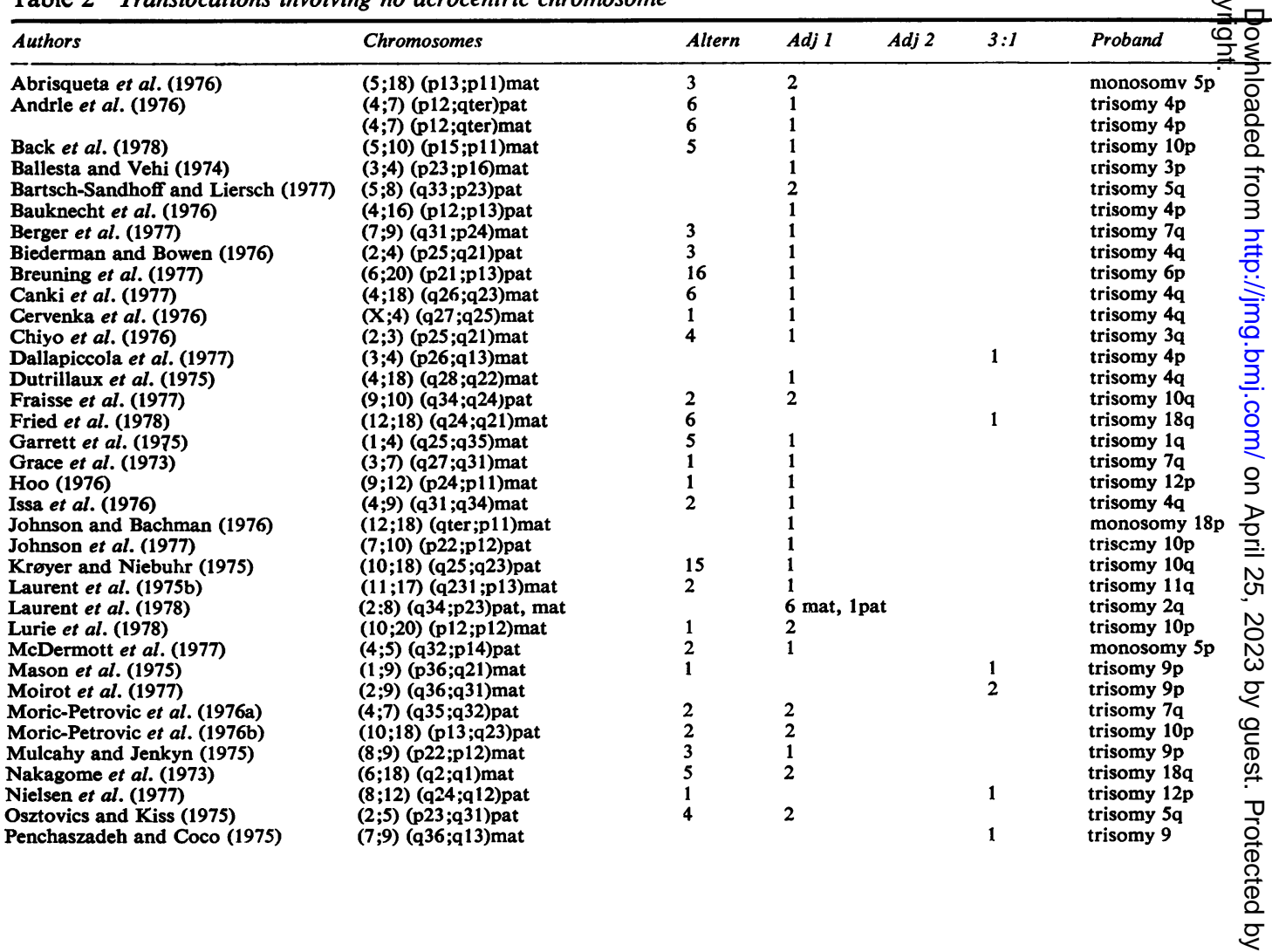


Table 2-continued

\begin{tabular}{|c|c|c|c|c|c|c|}
\hline Authors & Chromosomes & Altern & Adj 1 & Adj 2 & $3: 1$ & Proband \\
\hline 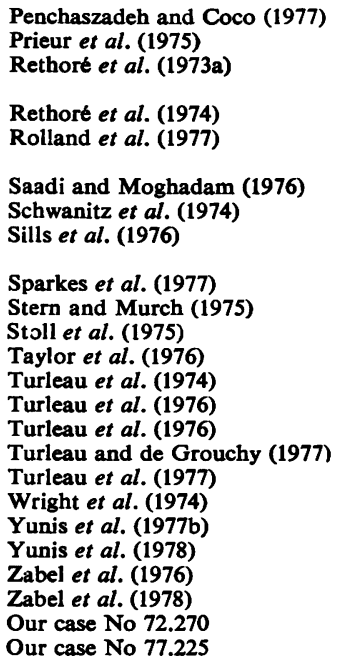 & $\begin{array}{l}(3 ; 10)(\mathrm{q} 28 ; \mathrm{q} 11) \mathrm{mat} \\
(10 ; 17)(\mathrm{q} 24 ; \mathrm{q} 25) \mathrm{pat} \\
(6 ; 9)(\mathrm{q} 25 ; \mathrm{q} 11) \mathrm{mat} \\
(9 ; 19)(\mathrm{p} 12 ; \mathrm{pter}) \mathrm{mat} \\
(4 ; 9)(\mathrm{q} 34 ; \mathrm{q} 21) \mathrm{mat} \\
(4 ; 10)(\mathrm{p} 16 ; \mathrm{p} 14) \text { pat } \\
(10 ; 12)(\mathrm{p} 11 ; \mathrm{q} 24) \mathrm{pat} \\
(5 ; 7)(\mathrm{q} 35 ; \mathrm{q} 31) \mathrm{pat} \\
(8 ; 9)(\mathrm{q} 24 ; \mathrm{q} 22) \mathrm{mat} \\
(2 ; 10)(\mathrm{q} 31 ; \mathrm{q} 24) \mathrm{pat} \\
\\
(4 ; 20)(\mathrm{q} 25 ; \mathrm{q} 13) \mathrm{mat} \\
(16 ; 18)(\mathrm{p} 12 ; \mathrm{q} 11) \mathrm{mat} \\
(9 ; 20)(\mathrm{q} 12 ; \mathrm{p} 13) \mathrm{mat} \\
(18 ; 20)(\mathrm{q} 23 ; \mathrm{p} 11) \mathrm{mat} \\
(7 ; 9)(\mathrm{q} 35 ; \mathrm{p} 13) \mathrm{mat} \\
(7 ; 18)(\mathrm{q} 333 ; \mathrm{q} 113) \mathrm{mat} \\
(4 ; 10)(\mathrm{q} 35 ; \mathrm{p} 11) \mathrm{mat} \\
(8 ; 18)(\mathrm{p} 23 ; \mathrm{q} 12) \mathrm{mat} \\
(\mathrm{X} ; 2)(\mathrm{p} 22 ; \mathrm{q} 32) \mathrm{mat} \\
(6 ; 11)(\mathrm{p} 23 ; \mathrm{q} 22) \mathrm{pat} \\
(4 ; 18)(\mathrm{q} 31 ; \mathrm{q} 23) \mathrm{mat} \\
(4 ; 5)(\mathrm{q} 32 ; \mathrm{p} 13) \text { pat } \\
(2 ; 12)(\mathrm{q} 31 ; \mathrm{q} 24) \mathrm{mat} \\
(3 ; 5)(\mathrm{p} 27 ; \mathrm{p} 13) \mathrm{mat} \\
(5 ; 18)(\mathrm{p} 12 ; \mathrm{p} 11) \mathrm{mat} \\
(5 ; 10)(\mathrm{p} 13 ; \mathrm{p} 15) \mathrm{pat}\end{array}$ & $\begin{array}{l}4 \\
4 \\
3 \\
2 \\
18 \\
3 \\
3 \\
2 \\
2 \\
1 \\
2 \\
6 \\
\\
3 \\
10 \\
2 \\
1 \\
4 \\
4\end{array}$ & $\begin{array}{l}1 \\
1 \\
1 \\
1 \\
1 \\
1 \\
1 \\
1 \\
2 \\
1 \\
1 \\
1 \\
1 \\
1 \\
1 \\
2 \\
2 \\
1 \\
1 \\
2 \\
3\end{array}$ & & $\begin{array}{l}1 \\
1\end{array}$ & $\begin{array}{l}\text { trisomy } 10 \mathrm{p} \\
\text { trisomy } 10 \mathrm{q} \\
\text { trisomy } 9 \mathrm{p} \\
\text { trisomy } 9 \mathrm{p} \\
\text { trisomy } 9 \mathrm{p} \\
\text { trisomy } 10 \mathrm{p} \\
\text { trisomy } 10 \mathrm{p} \\
\text { trisomy } 7 \mathrm{q} \\
\text { trisomy } 9 \mathrm{p} \\
\text { trisomy 1q } \\
\text { monosomy } 2 \mathrm{q} \\
\text { trisomy } 4 \mathrm{q} \\
\text { trisomy } 18 \\
\text { trisomy } 9 \mathrm{p} \\
\text { trisomy } 20 \mathrm{p} \\
\text { trisomy } 9 \mathrm{p} \\
\text { trisomy } 7 \mathrm{q} \\
\text { trisomy } 10 \mathrm{p} \\
\text { trisomy } 18 \mathrm{q} \\
\text { trisomy } 2 \mathrm{q} \\
\text { trisomy } 11 \mathrm{q} \\
\text { trisomy } 4 \mathrm{q} \\
\text { trisomy } 5 \mathrm{p} \\
\text { trisomy } 2 \mathrm{q} \\
\text { trisomy } 5 \mathrm{p} \\
\text { monosomy } 5 \mathrm{p} \\
\text { monosomy } 5 \mathrm{p}\end{array}$ \\
\hline
\end{tabular}

Table 3 Segregation of 161 reciprocal translocations; study of 121 probands and affected relatives

\begin{tabular}{lll}
\hline & No of families & No of affected members \\
\hline Adjacent 1 & 105 & 147 \\
$3: 1$ & 54 & 61 \\
Adjacent 2 & 7 & 13 \\
\hline
\end{tabular}

Table 4 Segregation of 98 translocations involving at least one acrocentric

\begin{tabular}{lll}
\hline Type & No of families & No of affected members \\
\hline Adjacent 1 & 54 & 76 \\
Adjacent 2 & 7 & 13 \\
$3: 1$ & 42 & 48 \\
\hline
\end{tabular}

Table 5 Segregation of 63 translocations involving no acrocentric

\begin{tabular}{lcc}
\hline Type & No of families & No of affected members \\
\hline Adjacent 1 & 51 & 71 \\
Adjacent 2 & 0 & 0 \\
$3: 1$ & 12 & 13 \\
\hline
\end{tabular}

and an acrocentric, even though the long arms (Rethoré et al., 1973b; Turleau et al., 1974) were involved.

None of the $\mathbf{3 0}$ families whose reciprocal translocation involved the short arm of an acrocentric showed the disjunction adjacent 2 .

A family incidence was noted 4 times out of 7 (Table 6). The distinction between two classes of family, according to whether they have one case or more than one case of the same type of disjunction, allows a comparison of the repetitiveness of the three types, adjacent 1 , adjacent 2 , and 3:1 (Table 7). The disjunction adjacent 1 is more repetitive than the type 3:1 ( $\mathrm{P}<0.02)$. The disjunction adjacent 2 seems more repetitive than adjacent 1 . The difference is not, however, significant in this small sample.

In addition, there are never adjacent 1 or $3: 1$ disjunctions in the families with adjacent 2 disjunction.

Finally for 12 of the 13 subjects, the adjacent 2 disjunction was derived from a maternal balanced translocation.

\section{$3: 1$ DISJUNCTIONS}

These disjunctions (subjects with 45 or 47 chromosomes) were more frequent in group I (Table 4) than in group II (Table 5). They affected more subjects and more families $(\mathbf{P}<\mathbf{0 . 0 1})$ and the acrocentrics involved were random. In group $\Pi$, they were more frequent when the translocation affected a chromosome 9 (8 of 16 as opposed to 5 of 68 translocations not involving No 9) $(\mathrm{P}<0.001)$ and their frequency in this case did not differ from that in group $\mathbf{I}$. In group I, the incidence of 3:1 disjunction seemed also to be higher when a No 9 was involved (12 of 24 as opposed to 35 of 101 in the absence of No 9). This difference was not, however, statistically significant $(0 \cdot 2>P>0 \cdot 1)$. The 3:1 disjunction resulted more often from a maternal translocation (55 times out of $61)$ than the adjacent 1 disjunction (97 times out of 147). The difference was significant $(P<0.001)$. 
Table $6 \quad 7$ families with adjacent 2 disjunction

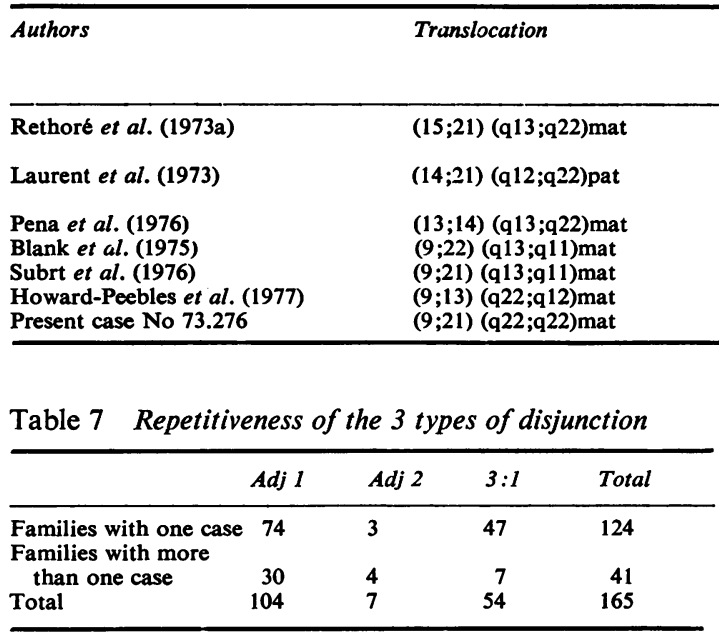

Moreover, the relative increase of the maternal origin in the imbalance was highest in the two types of translocation which often segregate according to the type 3:1: in group I, 111 times out of 137 , as opposed to 54 times out of 84 for group $\Pi(\mathrm{P}<0 \cdot 01)$; in group II, with the involvement of a No 9, 14 times out of 16 .

\section{Discussion}

\section{CHARACTERISTICS OF THE ADJACENT 2 DISJUNCTION}

This type of disjunction has never been the subject of an in-depth study because of its rarity. The true incidence of such a rare phenomenon cannot be fully appreciated from this retrospective investigation, the method of evaluation of which is biased. The present study shows its occurrence in only 7 of the 161 families recorded. It involves only 13 of the 221 abnormal subjects of these families. Before the advent of chromosome banding, Hamerton (1971) studied 75 families and only came across this phenomenon twice (his results are not included in this work). These two translocations show these common characteristics: at least one acrocentric is involved; no other type of disjunction (adjacent 1 or $3: 1$ ) occurs in the family; in spite of its rarity, adjacent 2 disjunction is repetitive ( 3 times in the family described by Uchida et al., 1964, and twice in the family described by Lord et al., 1967); these translocations are maternal.

These characteristics can now be stated more precisely.
The nature of the chromosomes involved

Translocations likely to result in adjacent 2 dis junction occur between the long arms of two acros centric chromosomes or between that of an acris centric and that of a No 9. The interstitial segments of the chromosomes involved are generally short; if they are not, they carry an extended heterochromatie zone, the 9qh.

The exclusive nature of the disjunction

Neither adjacent 1 nor 3:1 disjunction has bee found in the families with adjacent 2 disjunction However, the mutual exclusiveness of adjacent 2 and 3:1 disjunctions may only be related to the sroaf sample size. In comparison, the disjunctions adjacent 1 and 3:1 exist together in a limited number of cases (6 out of 54 families $3: 1$ ).

The repetitive nature of the disjunction

Adjacent 2 disjunction does recur; this is the case i⿱ 4 families out of 7. This repetitiveness is highest in the family described by Blank et al. (1975) which contains 4 disjunctions of the adjacent 2 type.

\section{The parental origins of the imbalance}

Adjacent 2 disjunction is nearly always maternab This feature is shared with the 3:1 disjunction bu not with adjacent 1 . Also, the imbalance, regardless. of its type, is more often maternal in origin each time that the translocation involves at least one acrocentric chromosome or a No 9 which, as previously mentioned, produces the disjunction adjacent 2 and 3:1.

\section{POSSIBLE MECHANISMS INDUCING ADJACENT 2 IMBALANCE}

The selection

In the family reported here the adjacent 2 disjunction does not produce duplication or deficiency of the translocated segments $9 q$ and $21 q$. It results, there? fore, in a moderate imbalance in contrast to that which might result from a disjunction of the typ $\overrightarrow{\bar{\theta}}$ 
adjacent 1 or $3: 1$. As a general rule, the adjacent 2 disjunctions produce duplication deficiency of the centric segments (arms not involved in the translocation and interstitial segments situated between the centromeres and the breakpoints). They do not affect the translocated segments (except for crossingover in the interstitial segments).

This feature is different from that in the adjacent 1 disjunctions where, under the same conditions (absence of crossing-over in the interstitial segment), the opposite is observed. Only the translocated segments are imbalanced. It is also different from that in the 3:1 disjunctions where the trisomy or monosomy involves both the centric segments and the translocated segments.

The long centric segments and the short translocated segments therefore predispose, by selection, to adjacent 1 disjunctions. Conversely, adjacent 2 disjunctions are more likely to produce a viable constitution when the translocated segments are important and the centric segments short. These observations recall those of Burnham (1950) who, in Zea mais, showed a proportional relationship between the shortness of the interstitial segments and the frequency of adjacent 2 disjunction. However, the interstitial segment is only a part of the centric segment; the other part (the arm not involved in the translocation) may have the same selective role.

Since the disjunctions adjacent 1 and 2 have an opposite effect, this may explain why they never coexist. If the translocated segments are short, type 1 is probable and type 2 would result in a lethal imbalance; the converse is true if these segments are long. The translocations involving the long arms of acrocentric chromosomes are therefore predisposed to this type of disjunction when breakpoints are juxtacentromeric because only imbalance of their short arms is produced. Similarly, when a chromosome 9 is involved, it is by its long arms and breakpoints lie at q13 or q21-22, never beyond. In these conditions the disjunction results in trisomy of the region $9 p$ and $9 q$ proximal, segments whose duplication is not lethal.

These points do not explain why other chromosomes (X or $\mathrm{Y}$ ), or other chromosome regions whose duplication or deficiency is not lethal, are never involved in these translocations. They also do not explain why adjacent 2 and 3:1 have not, as yet, been seen in the same family.

\section{Meiotic configurations}

Since this type of disjunction is determined at the time of the first meiotic division, the pachytene meiotic configurations are to be considered.

In this respect, two of the factors already mentioned as influencing the adjacent 2 disjunction by selection appear to favour this segregation through the meiotic configuration: shortness of the interstitial segment and participation of the acrocentric chromosomes.

(a) The shortness of the two interstitial segments, or rather the absence of crossing-over in them, may cause an error in tetravalent positioning which induces segregation to the same pole of the two homologous centromeres. This hypothesis is supported by the observation that the occurrence of crossing-over in the interstitial segments results in regular anaphase disjunction of homologous centromeres, thus preventing adjacent 2 disjunction (McClintock, 1945, on Neurospora crassa). The same observation has been made by Burnham (1950) with Zea mais. In four cases the adjacent 2 disjunction affects translocations with a long interstitial segment, but it is the heterochromatic $9 \mathrm{qh}$ which is likely to be achiasmatic, as suggested by the stability of the pericentric inversions of this region (Madan and Bobrow, 1974).

(b) The involvement of at least a pair of acrocentrics at the meiotic quadrivalent seems to be a determinant. Besides, it is necessary that the acrocentric be translocated by its long arm.

Under these conditions the tetrad shows one very short terminal segment which corresponds to the short arms of the acrocentrics. In this region, probably achiasmatic (Hulten, 1974), the tetravalent opens. Therefore, the complex formed is not circular; it is a chain, the two ends of which are occupied by the short arms of the acrocentrics. Lewis and John (1963) have shown in Chorthippus bruneus, an orthoptera, that this configuration, called type $\Pi$ chain (to differentiate it from that of type $I$, where the achiasmatic segment is the translocated segment), produced adjacent 2 disjunctions with a high frequency but never adjacent 1 . The analogy between this observation and that which takes place in man has already been suggested by Hamerton (1971).

CHARACTERISTICS OF THE 3:1 DISJUNCTION The sampling is too biased to allow an evaluation of the frequency of this type of disjunction or to estimate, even roughly, a recurrence risk. For example, observations on 3:1 disjunctions, which are partially pure monosomies or trisomies, are probably more often published than those cases of adjacent 1 disjunction which are duplication deficiencies.

According to Lindenbaum and Bobrow (1975) 3:1 disjunction is rare and represents 6 to $25 \%$ of the total of the imbalances caused by reciprocal translocations.

The influencing factors on this type of disjunction 
have been studied by Hamerton (1971) and Lindenbaum and Bobrow (1975). Only two points are considered here.

\section{The nature of the chromosomes involved in the translocation}

An acrocentric chromosome takes part most often in the translocation (50 out of 61 cases showing disjunction 3:1). Among these acrocentrics, those of $G$ group are not more often involved than those of $D$ group (22 G and $23 \mathrm{D}$ ). In 1975, Lindenbaum and Bobrow observed from their sample that 12 of the $25 \mathrm{C}$ group chromosomes involved in $3: 1$ disjunctions were No 9, and they suggested a possible influence of this chromosome on the frequency of this type of disjunction. The present study confirms this hypothesis: in group II (translocations without acrocentrics) the incidence of $3: 1$ disjunction differs according to whether a chromosome 9 is or is not involved in the translocation. In the first case it is $50 \%$ and in the second only $7 \%$.

\section{The parental origin of the translocation}

Of the 61 subjects, $55(90 \cdot 2 \%)$ with a $3: 1$ imbalance are the offspring of heterozygous women. For 3:1 and adjacent 2 disjunctions together, a maternal origin is observed 67 times out of $74(90.6 \%)$. By comparison, the origin of the adjacent 1 imbalance is maternal in only 97 out of 147 cases (65\%).

This maternal origin is observed in $81 \%$ of the two types of translocation which often segregate according to type 3:1 (group I and group II with involvement of a No 9). This is significantly reduced when neither an acrocentric nor a No 9 are involved in the translocation $(58 \%)$.

We thank Miss E. Blanc, Miss G. Chatain, Miss D. Chmara, and Mrs. C. Ostorero for cytological assistance, Mrs M. J. Bossan and Mrs F. Courty for typing the manuscript, and $\mathrm{Mr} \mathrm{J}$. Gilliotte for photographic assistance.

\section{References}

Abrisqueta, J. A., Perez, A., Aller, V., Del Mazo, J., Goday, C., Martin, M. A., and De Torres, M. L. (1976). Cri du chat syndrome and translocation $\mathrm{t}(5 \mathrm{p}-; 18 \mathrm{p}+)$. Journal de Génétique Humaine, 24, 173-182.

Abuelo, D., Peri, D. P., Henkle, C., and Richardson, A. (1977). Partial trisomy 8 (trisomy 8q2106 $\rightarrow 8 \mathrm{qter}$ ). Journal of Medical Genetics, 14, 463-465.

Alfi, O. S., Donnell, G. N., and Kramer, S. L. (1973). Partial trisomy of the long arm of chromosome no 7. Journal of Medical Genetics, 10, 187-189.

Andrle, M., Erlach, A., Killian, W., and Rett, A. (1976). Two cases of trisomy $4 p$ with translocation $t(4 p-; 7 q+)$ in several members of one family. Human Genetics, 33, 155-160.
Archidiacono, N., Rocchi M., de Vonderweid, U., 乌. Filippi, G. (1978). t $(9 / 22)$ with centric fission and translocation leading to a case of pure 9p trisomy in the offspring. Human Genetics, 40, 325-331.

Armendares, S., and Salamanca-Gomez, F. (1978). Pai $2 p$ trisomy (p21 $\rightarrow$ pter) in two siblings of a family witb a $2 p-; 15 q+$ translocation. Clinical Genetics, 13, 17-24.

Armendarcs, S., Salamanca-Gomez, F., Nava, S., Rami gegs, S., and Cantu, J. M. (1975). The 12p trisomy syndrome, Annales de Génétique, 18, 89-94.

Aurias, A., Turc, Cl., Michiels, Y., Sinet, P. M., Graveleau, D., and Lejeune, J. (1975). Deux cas de trisomie $\mathbf{P q}$ $(\mathrm{q} 231 \rightarrow$ qter) par translocation $\mathrm{t}(11 ; 22)(\mathrm{q} 231 ; \mathrm{q} 111) \mathrm{d} \overrightarrow{\mathrm{A}} \mathrm{s}$ deux familles différentes. Annales de Génétique, 18, 185-188.

Ayraud, N., Galiana, A., Llyod, M., and Deswarte, H. (1976). Trisomie $11 \mathrm{q}(\mathrm{q} 231 \rightarrow$ qter) par translocation maternelle $t(11 ; 22)(q 231 ; q 111)$. Une nouvelle observation. Annales de Génétique, 19, 65-68.

Baccichetti, C., Tenconi, R., Anglani, F., and Zacchello, 'F. (1975). Trisomy $4 q 32 \rightarrow 4 q$ ter due to a maternal $4 \% 1$ translocation. Journal of Medical Genetics, 12, 425-427?

Back, E., Vogel, W., Hertel, C., and Schuchmann, L. (197\$). Trisomy $10 \mathrm{p}$ due to $\mathrm{t}(5 ; 10)(\mathrm{p} 15 ; \mathrm{p} 11)$ segregating in a largte sibship. Human Genetics, 41, 11-17.

Balicek, P., Zizka, J., and Lichy, J. (1975). A case of trisomy $9 p$ in a family with translocation $9 / 15$. Humangenetik, 27 , 353-358.

Ballesta, F., and Vehi, L. (1974). Trisomie partielle pour partie distale du bras court du chromosome 3. Annales Génétique, 17, 287-290.

Bartsch-Sandhoff, M., and Liersch, R. (1977). Partial duplication 5q syndrome: phenotypic similarity in t $\overrightarrow{w 0}$ sisters with identical karyotype (partial duplication $5 \mathrm{q} 33$ छै 5 ter and partial deficiency $8 \mathrm{p} 23 \rightarrow$ pter). Annale de Génétique, 20, 281-284.

Bass, H. N., Sparkes, R. S., Crandall, B. F., Galos, and Howard, J. (1978). A 45, XX, -5, -14,+t(5q;14q)m cri du chat child. Annales de Génétique, 21, 56-59.

Bauknecht, Th., Betteken, F., and Vogel, W. (1976). Trisoñgy $4 \mathrm{p}$ due to a paternal $\mathrm{t}(4 \mathrm{p}-; 16 \mathrm{p}+)$ translocation. Hum $\mathrm{an}$ Genetics, 34, 227-230.

Bergamo, F., Crosato, F., Francesconi, D., Pasquali, F., a䇉 Zuffardi, O. (1977). The 9p - deletion syndrome. A patient with a $45, X X,-9,-15,+t(9 / 15)$ constitution due

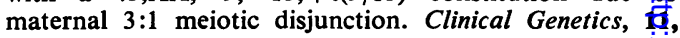
219-223.

Berger, R., Turc, C., Wachter, H., and Begue, G. (197 $\bar{\nexists}$. Partial 7q trisomy. Clinical Genetics, 11, 39-42.

Biederman, B., and Bowen, P. (1976). Partial trisomy 4q dige to familial 2/4 translocation. Human Genetics, 33, 147-153:

Biederman, B., Bowen, P., Robertson, C., and Schiff, B. (1977). Partial trisomy 12p due to $\mathrm{t}(12 ; 21)$ pat translocation. Human Genetics, 36, 35-41.

Blank, C. E., Colver, D. C. B., Potter, A. M., McHugh, 옹 and Lorber, J. (1975). Physical and mental defect of chro mosomal origin in four individuals of the same famia. Trisomy for the short arm of 9. Clinical Genetics, 261-273.

Borgaonkar, D. S., McKusick, V. A., and Farber, P. (1973). An inherited small extra chromosome: a mother with $46, X X, t(17 ; 22)(p 1 ; q 1)$ and a son with $47, X Y,+$ def (22)mat. Journal of Medical Genetics, 10, 379-383.

Breuning, M. H., Bijlsma, J. B., and de France, H. F. (1977). Partial trisomy $6 \mathrm{p}$ due to familial translocation $\mathrm{t}(6 ; 20)$ (p21;p13). A new syndrome? Human Genetics, 38, 7-13

Brimblecombe, F. S. W., Lewis, F. J., and Vowles, M. (197\% Complete 5p trisomy: 1 case and 19 translocations in 6 generations. Journal of Medical Genetics, 14, 271-275. 
Burnham, C. R. (1950). Chromosome segregation in translocations involving chromosome 6 in maize. Genetics, 35 , 446-481.

Canki, N., Debevec, M., Rainer, S., and Rethoré, M. O. (1977). Trisomie $4 \mathrm{q} 26 \rightarrow 4 \mathrm{qter}$ par translocation $\mathrm{t}(4 ; 18)$ (q26;q23)mat. Annales de Génétique, 20, 195-198.

Cantu, J. M., Salamanca-Gomez, F., Buentello, L., Carnevale, A., and Armendares, S. (1975). Trisomy 10p. A report of two cases due to a familial translocation $\operatorname{rcp}(10 ; 21)$ (p11;p11). Annales de Génétique, 18, 5-11.

Castel, Y., Riviere, D., Boucly, J. Y., and Toudic, L. (1976). Trisomie $15 \mathrm{q}$ partielle par translocation maternelle $\mathrm{t}(7 ; 15)$ (q35;q14). Annales de Génétique, 19, 75-79.

Centerwall, W., and Francke, U. (1977). Familial trisomy 20p. Five cases and two carriers in three generations. A review. Annales de Génétique, 20, 77-83.

Centerwall, W. R., Miller, K. S., and Reeves, L. M. (1976). Familial 'partial 9p' trisomy: six cases and four carriers in three generations. Journal of Medical Genetics, 13, 57-61.

Cervenka, J., Djavadi, G. R., and Gorlin, R. J. (1976). Partial trisomy $4 \mathrm{q}$ syndrome: case report and review. Human Genetics, 34, 1-7.

Chaganti, R. S. K., Morillo-Cucci, G., Friis, L., Degnan, M., and German, J. (1976). De novo appearance of a translocation $t(5 p ; 21 q)$ and its transmission in both balanced and unbalanced forms to the next generation. Annales de Génétique, 19, 43-48.

de la Chapelle, A., Koivisto, M., and Schroder, J. (1973). Segregating reciprocal $(4 ; 21)(\mathrm{q} 21 ; \mathrm{q} 21)$ translocation with proposita trisomic for parts of $4 \mathrm{q}$ and 21 . Journal of Medical Genetics, 10, 384-389.

Chiyo, H. A., Nakagome, Y., Matsui, I., Kuroki, Y., Kobayashi, H., and Ono, K. (1975). Two cases of $8 p$ trisomy in one sibship. Clinical Genetics, 7, 328-333.

Chiyo, H. A., Kuroki, Y., Matsui, I., Niitsu, N., and Nakagome, Y. (1976). A case of partial trisomy 3q. Journal of Medical Genetics, 13, 525-527.

Coco, R., and Penchaszadeh, V. B. (1977). Partial trisomy $14 \mathrm{q}$ and familial translocation $(2 ; 14)(\mathrm{q} 12 ; \mathrm{q} 13)$. Annales de Génétique, 20, 41-44.

Cohen, M. M., Davidson, R. G., and Brown, J. A. (1975a). A familial $F / G$ translocation $t(20 p-; 22 q+)$ observed in three generations. Clinical Genetics, 7, 120-127.

Cohen, M. M., Ornoy, A., Rosenmann, A., and Kohn, G. (1975b). An inherited translocation $\mathrm{t}(14 ; 15)$ (p16;q22) leading to two cases of partial trisomy 15. Annales de Génétique, 18, 99-103.

Dallapiccola, B., Mastroiacovo, P. P., Montali, E., and Sommer, A. (1977). Trisomy 4p: five new observations and overview. Clinical Genetics, 12, 344-356.

Darmady, J. M., and Seabright, M. (1975). A family with an inherited translocation involving the No $4 /$ No 21 chromosomes. Journal of Medical Genetics, 12, 408-411.

Dutrillaux, B., Laurent, C., Forabosco, A., Noel, B., Suerinc, E., Biemont, M. Cl., and Cotton, J. B. (1975). La trisomie $4 \mathrm{q}$ partielle. A propos de 3 observations. Annales de Génétique, 18, 21-27.

Forabosco, A., Dutrillaux, B., Toni, G., Tamborino, G., and Cavazzutti, G. (1973). Translocation équilibrée $t(2 ; 13)$ (q32;q33) familiale et trisomie 2q partielle. Annales de Génétique, 16, 255-258.

Ford, C. E., and Clegg, H. M. (1969). Reciprocal translocations. British Medical Bulletin, 25, 110-114.

Fraisse, J., Lauras, B., Laselve, A., and Freycon, F. (1977). Deux nouveaux cas de trisomie $10 \mathrm{q} 24 \rightarrow 10 \mathrm{qter}$ chez deux soeurs par translocation paternelle $\mathrm{t}(9 ; 10)(\mathrm{q} 34 ; \mathrm{q} 24)$. Annales de Génétique, 20, 128-131.

Fried, K., Bar-Yochai, A., Rosenblatt, M., and Mundel, G.
(1978). Partial 18 trisomy (with 47 chromosomes) resulting from a familial maternal translocation. Journal of Medical Genetics, 15, 76-78.

Fried, K., Tieder, M., Beer, S., Rosenblatt, M., and Krespin, H. I. (1977). Mental retardation with 45 chromosomes, $45, X X,-5,-14,+\operatorname{der}(5) t(5 ; 14) \quad(\mathrm{p} 15 ; \mathrm{q} 13)$ mat due to familial balanced reciprocal translocation. Journal of Medical Genetics, 14, 68-72.

Fryns, J. P., Van Eygen, M., Tanghe, W., and Van Den Berghe, H. (1977). Partial trisomy $14 q$ due to familial $\mathrm{t}(14 \mathrm{q}-, 11 \mathrm{q}+)$ translocation. Human Genetics, 37, 105-110.

Fu, W. N., Borgaonkar, D. S., Ladewig, P. P., Weaver, J., and Pomerance, H. H. (1976). Structural aberrations of the long arm of chromosome no 22 . Report of a family with translocation $\mathrm{t}(11 ; 22)(\mathrm{q} 25 ; \mathrm{q} 11)$. Clinical Genetics, 10, 329-336.

Garlinger, P., McGeary, S. A., and Magenis, E. (1977). Partial trisomy 22: a recognizable syndrome. Clinical Genetics, 12, 9-16.

Garrett, J. H., Finley, S. C., and Finley, W. H. (1975). Fetal loss and familial chromosome 1 translocations. Clinical Genetics, 8, 341-348.

Genest, P., Roussy, J., Genest, F. B., and Dumas, L. (1977). La trisomie 9p. Un cas de translocation $\mathrm{t}(9 ; 22)(\mathrm{p} 11 ; \mathrm{p} 11)$ mat chez une fillette. Union Médicale du Canada, 106, 956-959.

Giovannelli, G., Forabosco, A., and Dutrillaux, B. (1974). Translocation familiale $\mathrm{t}(4 ; 22)$ (p11;p12) et trisomie $4 \mathrm{p}$ chez deux germains. Annales de Génétique, 17, 119-124.

Giraud, F., Mattei, J. F., and Mattei, M. G. (1977). Trisomie 13 partielle par translocation $\mathrm{t}(2 ; 13)$ maternelle. Annales de Génétique, 20, 203-208.

Grace, E., Sutherland, G. R., Stark, G. D., and Bain, A. D. (1973). Partial trisomy of $7 q$ resulting from a familial translocation. Annales de Génétique, 16, 51-54.

Habedank, M., and Faust, J. (1978). Trisomy 9p and unusual translocation mongolism in siblings due to different $3: 1$ segregations of maternal translocation $\operatorname{rcp}(9 ; 21)(\mathrm{p} 11 ; \mathrm{q} 11)$. Human Genetics, 42, 251-256.

Hamerton, J. (1971). Chromosome translocations. In Human Cytogenetics, Vol. 1, pp. 247-272. Academic Press, New York.

Hansteen, I. L., Schirmer, L., and Hestetun, S. (1978). Trisomy $12 p$ syndrome. Evaluation of a family with a $t(12 ; 21)$ (p12.1;p11) translocation with unbalanced offspring. Clinical Genetics, 13, 339-349.

Hobolth, N., Jacobsen, P., and Mikkelsen, M. (1974). Partial trisomy 12 in a mentally retarded boy and translocation $(12 ; 21)$ in his mother. Journal of Medical Genetics, 11, 299-302.

Hoo, J. J. (1976). 12p trisomy: a syndrome? Annales de Génétique, 19, 261-263.

Howard-Peebles, P. N., Yarbrough, K. M., Stoddard, G. R., and Rary, J. M. (1977). Translocation $9 q / 13 q$ resulting in duplication (trisomy 9 pter $\rightarrow 9 q 22$ ) and deficiency (monosomy 13pter $\rightarrow 13$ q12). Clinical Genetics, 11, 46-52.)

Hulten, M. (1974). Chiasma distribution at diakinesis in the normal human male. Hereditas, 76, 55-78.

Hustinx, Th. W. J., Gabreels, F. J. M., Kirkels, V. G. H. J., Korten, J. J., Scheres, J. M. J. C., Joosten, E. M. G., and Rutten, F. J. (1975). Trisomy $4 p$ in a family with a $t(4 ; 15)$. Annales de Génétique, 18, 13-19.

Hustinx, Th. W. J., Ter Haar, B. G. A., Scheres, J. M. J. C., and Rutten, F. J. (1974). Trisomy for the short arm of chromosome no 10. Clinical Genetics, 6, 408-415.

Issa, M., Potter, A. M., and Blank, C. E. (1976). Multiple congenital defects associated with trisomy for long arm of no 4. Journal of Medical Genetics, 13, 326-329. 
Jenkins, M. B., and Boyd, L. (1976). Reciprocal translocation, $4 q-; 21 p+$, giving rise to Down's syndrome. Journal of Medical Genetics, 13, 323-326.

Johnson, G., and Bachman, R. (1976). A 46,XY,del(18)(pter $\rightarrow \mathrm{p} 1100)$ cebocephalic child from a $46, \mathrm{XX}, \mathrm{t}(12 ; 18)$ $(18$ pter $\rightarrow 18$ p1100::12qter $\rightarrow 12$ pter) normal parent. Human Genetics, 34, 103-106.

Johnson, G., Bachman, R., Roed, T., and Riddervold, P. (1977). Partial trisomy $10 \mathrm{p}$ and familial translocation $\mathrm{t}(7 ; 10)$ (p22;p12). Human Genetics, 35, 353-356.

Jotterand, M., and Juillard, E. (1976). A new case of trisomy for the distal part of $13 \mathrm{q}$ due to maternal translocation $\mathrm{t}(9 ; 13)$ (p21;q21). Human Genetics, 33, 213-222.

Kajii, T., Meylan, J., and Mikamo, K. (1974). Chromosome anomalies in three successive abortuses due to paternal translocation $t(13 q-18 q+)$. Cytogenetics and Cell Genetics, 13, 426-436.

Kessel, E., and Pfeiffer, R. A. (1977). 47,XY, $+\operatorname{der}(11 ; 22)$ (q23;q12) following balanced translocation $t(11 ; 22)$ (q23;q12)mat. Remarks on the problem of trisomy 22. Human Genetics, 37, 111-116.

Kim, H. J., Hsu, L. Y. F., Goldsmith, L. C., Strauss, L., and Hirschhorn, K. (1977). Familial translocation with partial trisomy of 13 and 22: evidence that specific regions of

chromosomes 13 and 22 are responsible for the phenotype of each trisomy. Journal of Medical Genetics, 14, 114-119.

Krøyer, S., and Niebuhr, E. (1975). Partial trisomy 10q occurring in a family with a reciprocal translocation $\mathrm{t}(10 ; 18)(\mathrm{q} 25 ; \mathrm{q} 23)$. Annales de Génétique, 18, 50-55.

Lange, M., and Alfi, O. S. (1976). Trisomy 19q. Annales de Génétique, 19, 17-21.

Larson, L. M., Wasdahl, W. A., and Jalal, S. M. (1977). Partial trisomy $7 p$ associated with familial $7 p ; 22 q$ translocation. Journal of Medical Genetics, 14, 258-261.

Laurent, C., Biemont, M. Cl., Bethenod, M., Cret, L., and David, M. (1975a). Deux observations de trisomie 11q (q231 $\rightarrow$ qter) avec la même anomalie des organes génitaux externes. Annales de Génétique, 18, 179-184.

Laurent, C., Biemont, M. Cl., Cognat, M., and Dutrillaux, B. (1975b). Studies of the meiotic behaviour of a translocation $\mathrm{t}(10 ; 13)(\mathrm{q} 25 ; \mathrm{q} 11)$ in an oligospermic man. Human Genetics, $39,123-126$.

Laurent, C., Biemont, M. Cl., Guibaud, P., Guillot, J., Noel, B., Quack, B., Genevieve, M., and Cressens, M. L. (1978). Sept cas de trisomie $2 q 34 \rightarrow 2 q$ ter par transmission familiale d'une translocation $\mathrm{t}(2 ; 8)(\mathrm{q} 34 ; \mathrm{p} 23)$. Annales de Génétique, 21, 13-18.

Laurent, C., Dutrillaux, B., Biemont, M. Cl., Genoud, J., and Bethenod, M. (1973). Translocation t(14q-;21q+) chez le père, trisomie 14 et monosomie 21 partielles chez la fille. Annales de Génétique, 16, 281-284.

Lejeune, J., Dutrillaux, B., and de Grouchy, J. (1970). Reciprocal translocations in human populations. A preliminary analysis. In Human Population Cytogenetics, pp. 81-87, ed P. A. Jacobs, W. H. Price, and P. Law. University of Edinburgh Press, Edinburgh.

Lewis, K. R., and John, B. (1963). Spontaneous interchange in Chorthippus brunneus. Chromosoma, 14, 618-637.

Lindenbaum, R. H., and Bobrow, M. (1975). Reciprocal translocations in man. 3:1 meiotic disjunction resulting in 47 or 45 chromosome offspring. Journal of Medical Genetics, 12, 29-43.

Lord, P. M., Casey, M. D., and Laurance, B. M. (1967). A new translocation between chromosomes in the 6-12 and 21-22 groups. Journal of Medical Genetics, 4, 169-176.

Lurie, I. W., Lazjuk, G. I., Gurevich, D. B., Kravtzova, G. I., Nedzved, M. K., and Shved, I. A. (1978). Partial trisomy 10p in two generations. Human Genetics, 41, 235-241.
McClintock, B. (1945). Neurospora. I. Preliminary obserfations of the chromosomes of Neurospora crassa. American Journal of Botany, 32, 671-678.

McDermott, A., Poulding, R., and Creery, D. (1977). Cri-dichat syndrome in a child with a 46,XX,der(5),t(4,5) (q32;p14)pat karyotype. Human Genetics, 39, 109-112-0

Madan, K., and Bobrow, M. (1974). Structural variation-in chromosome no 9. Annales de Génétique, 17, 81-86.

Mason, M. K., Spencer, D. A., and Rutter, A. (1975). A ç of partial (9p) trisomy in a family with a balanced trasslocation 46,XX,t(1p+9q-). Journal of Medical Genetiss, 12, 310-315.

Moirot, H., Fessard, Cl., and Hemet, J. (1977). Trisomie-9p par $\mathrm{t}(2 ; 9)(\mathrm{q} 36 ; \mathrm{q} 31) \mathrm{mat}$. Annales de Génétique, 20, 45-51.

Moric-Petrovic, S., Laca, Z., and Krajgher, A. (1976a). Translocation réciproque dans la famille de deux progesants avec une trisomie partielle du chromosome Annales de Génétique, 19, 133-136.

Moric-Petrovic, S., Laca, Z., Krajgher, A., and Milosevic,J. (1976b). Deux cas de trisomie 10p partielle dûs à translocation paternelle $\mathrm{t}(10 ; 18)(\mathrm{p} 13 ; \mathrm{q} 23)$. Annales. $\mathrm{de}$ Génétique, 19, 195-197.

Mulcahy, M. T., and Jenkyn, J. (1975). The 9p trisondy syndrome: two further cases arising from different famifal translocations. Clinical Genetics, 8, 199-204.

Nakagome, Y., Icnuma, K., and Matsui, I. (1973). Threge translocations involving $\mathbf{C}$ or $\mathbf{G}$ group chromosoms. Journal of Medical Genetics, 10, 174-177.

Nakagome, Y., and Kobayashi, H. (1975). Trisomy of the short arm of chromosome 10. Journal of Medical Genet $12,412-414$.

Niazi, M., Coleman, D. V., and Saldana-Garcia, P. (1978). Partial trisomy 18 in a family with a translocation $(B ; 1)$ (q21;q22). Journal of Medical Genetics, 15, 148-151

Nielsen, J., Rasmussen, K., Lassen, L. B., and Christiansen CFF. (1976). A family with a high risk of segregation for arfat somal unbalanced reciprocal translocation. Hutman Genetics, 32, 343-348.

Nielsen, J., Vetner, M., Holm, V., Askjaer, S. A., 要d Reske-Nielsen, E. (1977). A newborn child with karyot $47, X X,+\operatorname{der}(12) \quad(12 p t e r \rightarrow 12 q 12:: 8 q 24 \rightarrow 8 q t e r), t\left(8 ; \frac{12}{;}\right)$ (q24;q12)pat. Human Genetics, 35, 357-362.

Noel, B., Levy, M., and Rethoré, M. O. (1976a). Triso partielle du bras long du chromosome 11 par malsegregation d'une translocation maternelle $\mathrm{t}(11 ; 22)$ (q231;q1 $\mathrm{A})$. Annales de Génétique, 19, 137-139.

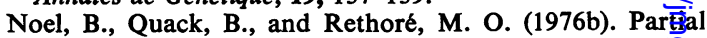
deletions and trisomies of chromosome 13; mappingof bands associated with particular malformations. Clin Ėal Genetics, 9, 593-602.

Orye, E., Verhaaren, H., and Van Den Bogaert-Van Hėsvelde, A. M. (1975). The 9p - deletion syndrome. Repgrt of a patient with a $46, X X, 9 p-$ constitution due to a paternal $\mathrm{t}(9 \mathrm{p}-; 15 \mathrm{q}+)$ translocation. Clinical Genet fs $_{\mathrm{s}}$, 8, 349-357.

Osztovics, M., and Kiss, P. (1975). Familial translocat黑 $\mathrm{t}(2 ; 5)$ (p23;q31). Clinical Genetics, 8, 112-116.

Owen, L., Martin, B., Blank, C. E., and Harris, F. (19t5). Multiple congenital defects associated with trisomy for the short arm of chromosome 4. Journal of Medical Genet 11, 291-296.

Pena, S. D. J., Ray, M., McAlpine, P. J., Ducasse, ש્ટ., Briggs, J., and Hamerton, J. L. (1976). Tertiary trisomy 4 : is there a syndrome? Birth Defects: Original Arte Series, 12, 113-118.

Penchaszadeh, V. B., and Coco, R. (1975). Partial 9 trisofiny by $3: 1$ segregation of balanced maternal translocation $(7 q+; 9 q-)$. Journal of Medical Genetics, 12, 301-304. 
Penchaszadeh, V. B., and Coco, R. (1977). Trisomy for the short arm of chromosome no 10. Journal de Génétique Humaine, 25, 221-227.

Pfeiffer, R. A., and Kessel, E. (1976). Partial trisomy $15 q 1$. Human Genetics, 33, 77-83.

Pfeiffer, R. A., Kessel, E. K., and Soer, K. M. (1977). Partial trisomies of chromosome 21 in man. Two new observations due to translocations $19 ; 21$ and $4 ; 21$. Clinical Genetics, 11, 207-213.

Philippe, N., Requin, C., Germain, D., Licheron, A., and Hermier, M. (1975). Trisomie 9p par translocation maternelle $(9 ; 22)$ (p11;q11). Journal de Génétique Humaine, 23 , 309-317.

Podruch, P. E., and Weisskopf, B. (1974). Trisomy for the short arms of chromosome 9 in two generations, with balanced translocations $\mathrm{t}(15 \mathrm{p}+; 9 \mathrm{q}-)$ in three generations. Journal of Pediatrics, 85, 92-95.

Prieur, M., Forabosco, A., Dutrillaux, B., Laurent, C., Bernasconi, S., and Lejeune, J. (1975). La trisomie $10 \mathrm{q} 24 \rightarrow 10 \mathrm{qter}$. Annales de Génétique, 18, 217-222.

Raoul, O., Carpentier, S., Dutrillaux, B., Mallet, R., and Lejeune, J. (1976). Trisomies partielles du chromosome 21 par translocation maternelle $\mathrm{t}(15 ; 21)(\mathrm{q} 262 ; \mathrm{q} 21)$. Annales de Génétique, 19, 187-190.

Raoul, O., Rethoré, M. O., Dutrillaux, B., Michon, L., and Lejeune, J. (1975). Trisomie 14q partielle. I. Trisomie 14q partielle par translocation maternelle $\mathrm{t}(10 ; 14)(\mathrm{p} 152 ; \mathrm{q} 22)$. Annales de Génétique, 18, 35-39.

Rethoré, M. O., Dutrillaux, B., and Lejeune, J. (1973a). Translocation $46, X X, t(15 ; 21)(q 13 ; q 22,1)$ chez la mère de deux enfants atteints de trisomie 13 et de monosomie 21 partielles. Annales de Génétique, 16, 271-275.

Rethoré, M. O., Ferrand, J., Dutrillaux, B., and Lejeune, J. (1974). Trisomie 9p par t(4;9) (q34;q21)mat. Annales de Génétique, 17, 157-161.

Rethoré, M. O., Hoehn, H., Rott, H. D., Couturier, J., Dutrillaux, B., and Lejeune, J. (1973b). Analyse de la trisomie 9p par dénaturation ménagée. A propos d'un nouveau cas. Humangenetik, 18, 129-138.

Rethoré, M. O., Kaplan, J. C., Junien, Cl., Cruveiller, J., Dutrillaux, B., Aurias, A., Carpentier, S., Lafourcade, J., and Lejeune, J. (1975). Augmentation de l'activité de la LDH-B chez un garçon trisomique $12 \mathrm{p}$ par malségrégation d'une translocation maternelle $\mathrm{t}(12 ; 14)(\mathrm{q} 12 ; \mathrm{p} 11)$. Annales de Génétique, 18, 81-87.

Rolland, M., Bourrouillou, G., Elana, G., Colombies, P., and Regnier, C. (1977). Trisomie 10p partielle d'origine paternelle. Deux nouvelles observations dans deux familles différentes. Annales de Génétique, 20, 209-213.

Rosenmann, A., Isacson, M., Cohen, R., Segal, M., and Cohen, M. M. (1978). Partial trisomy 18 (q11 $\rightarrow$ qter) in an infant and aborted fetus resulting from a balanced paternal translocation t $(13 ; 18)(\mathrm{q} 32 ; \mathrm{q} 11)$. Annales de Génétique, 21 , 60-64.

Roux, C., Taillemite, J. L., and Baheux-Morlier, G. (1974). Trisomie partielle $10 \mathrm{q}$ par translocation familiale $\mathrm{t}(10 \mathrm{q}-$; $22 \mathrm{p}+$ ). Annales de Génétique, 17, 59-62.

Saadi, A. A., and Moghadam, H. A. (1976). Partial trisomy of the long arm of chromosome 7. Clinical Genetics, 9, 250-254.

Sanchez, O., Mamunes, P., and Yunis, J. J. (1977). Partial trisomy 20 (20q13) and partial trisomy 21 (21 pter $\rightarrow 21 \mathrm{q} 213)$. Journal of Medical Genetics, 14, 459-462.

Schinzel, A., Hayashi, K., and Schmid, W. (1976). Further delineation of the clinical picture of trisomy for the distal segment of chromosome 13. Report of three cases. Human Genetics, 32, 1-12.

Schrott, H. G., Sakaguchi, S., Francke, U., Luzzatti, L., and Fialkow, P. J. (1974). Translocation $t(4 q-; 13 q+)$ in three generations resulting in partial trisomy of the long arm of chromosome 4 in the fourth generation. Journal of Medical Genetics, 11, 201-205.

Schwanitz, G., and Grosse, K. P. (1973). Partial trisomy 4p with translocation $4 p-, 22 p+$ in the father. Annales de Génétique, 16, 263-266.

Schwanitz, G., Schamberger, U., Rott, H. D., and Wieczorec, V. (1974). Partial trisomy 9 in the case of familial translocation 8/9 mat. Annales de Génétique, 17, 163-166.

Schwanitz, G., Schmid, R. D., Grosse, G., and Grahn-Liebe, E. (1977). Translocation familiale $3 / 22$ mat avec trisomie partielle 3q. Journal de Génétique Humaine, 25, 141-150.

Short, E. M., Solitare, G. B., and Breg, W. R. (1972). A case of partial 14 trisomy. $47, X Y,(14 q-)+$ and translocation $\mathrm{t}(9 \mathrm{p}+; 14 \mathrm{q}-)$ in mother and brother. Journal of Medical Genetics, 9, 367-373.

Sills, J. A., Buckton, K. E., and Raeburn, J. A. (1976). Severe mental retardation in a boy with partial trisomy $10 \mathrm{q}$ and partial monosomy 2q. Journal of Medical Genetics, 13, 507-510.

Simpson, J., and Zellweger, H. (1977). Partial trisomy 14qand parental translocation of no 14 chromosome. Report of a case and review of the literature. Journal of Medical Genetics, 14, 124-127.

Sparkes, R. S., Francke, U., Muller, H., and Toomey, K. (1977). Partial 4q duplication due to inherited der(20), $\mathrm{t}(4 ; 20)$ (q25;q13)mat. Annales de Génétique, 20, 31-35.

Stern, L. M., and Murch, A. R. (1975). Pseudohermaphroditism with clinical features of trisomy 18 in an infant trisomic for parts of chromosomes 16 and 18: 47,XY,der (18),t(16;18) (p12;q11)mat. Journal of Medical Genetics, 12, 305-308.

Stoll, C., Levy, J. M., and Gardea, A. (1975). Trisomy 9p in a girl whose mother has a translocation $t(9 ; 20)$ (q12;p13). Humargenetik, 27, 269-274.

Stoll, C., Messer, J., and Vors, J. (1974). Translocation $t(2 ; 14)$ équilibrée chez une mère et trisomie partielle d'une partie du bras court d'un chromosome no 2 chez deux de ses enfants. Annales de Génétique, 17, 193-196.

Subrt, I., Blehova, B., and Pallova, B. (1976). Trisomy 9p resulting from maternal $9 / 21$ translocation. Human Genetics, 32, 217-220.

Surana, R. B., Braudo, M. E., Conen, P. E., and Slade, R. H. (1977). 46,XY,t $(3 ; 22)$ (p2; 13$)$ resulting in partial trisomy for the short arm of chromosome 3. Clinical Genetics, 11, 201-206.

Taylor, K. M., Wolfinger, H. L., Brown, M. G., Chadwick. D. L., and Francke, U. (1976). Partial trisomy 20p derived from a t(18;20) translocation. Human Genetics, 34, 155-162.

Turleau, C., Chavin-Colin, F., de Grouchy, J., Repesse, G., and Beauvais, P. (1977). Familial $t(X ; 2)(p 223 ; q 323)$ with partial trisomy $2 \mathrm{q}$ and male and female balanced carriers. Human Genetics, 37, 97-104.

Turleau, C., and de Grouchy, J. (1977). Trisomy 18qter and trisomy mapping of chromosome 18. Clinical Genetics, 12, 361-371.

Turleau, C., de Grouchy, J., Bocquentin, F., Roubin, M., and Chavin-Colin, F. (1975). Trisomie 14q partielle. II. Trisomie 14q partielle par translocation maternelle $(12 ; 14)$ (q244;q21). Annales de Génétique, 18, 41-44.

Turleau, C., de Grouchy, J., Chavin-Colin, F., Roubin, M., and Langmaid, H. (1974). Trisomie 9p: deux nouvelles observations. Annales de Génétique, 17, 167-174.

Turleau, C., Doussau de Bazignan, M., Roubin, M., and de Grouchy, J. (1976). Trisomie 10p. Une observation ancienne précisée par marquage. Annales de Génétique, 19, 61-64. 
Uchida, I. A., Wang, H. C., Laxdal, O. F., Zaleski, W. A., and Duncan, B. P. (1964). Partial trisomy deficiency syndrome resulting from a reciprocal translocation in a large kindred. Cytogenetics, 3, 81-96.

Vogel, W., Siebers, J. W., and Reinwein, H. (1973). Partial trisomy 7q. Annales de Génétique, 16, 277-280.

Wilroy, R. S. (1977). Partial monosomy and partial trisomy for different segments of chromosome 13 in several individuals of the same family. Annales de Génétique, 20, 237-242.

Wright, Y., Clark, W. E., and Breg, W. R. (1974). Craniorachischisis in a partially trisomic 11 fetus in a family with reproductive failure and a reciprocal translocation $\mathrm{t}(6 \mathrm{p}+; 11 \mathrm{q}-)$. Journal of Medical Genetics, 11, 69-76.

Young, S. R., Donovan, D. M., Greer, H. A., Burch, K., and Potter, D. C. (1976). Tertiary trisomy $47, \mathrm{XX},+14 \mathrm{q}-$, resulting from maternal balanced translocation, $46, \mathrm{XX}$, $\mathrm{t}(14 ; 16)$ (q11;q24). Human Genetics, 33, 331-334.

Yunis, E., Gonzales, J. T., and de Caballero, O. M. T. (1977a). Partial trisomy 16q -. Human Genetics, 38, 347-350.

Yunis, E., Giraldo, A., Zuniga, R., Egel, H., and Ramirez, E. (1977b). Partial trisomy 4q. Annales de Génétique, 20, 243-248.
Yunis, E., Silva, R., Egel, H., Zuniga, R., de CaballerQ, O. M. T., Ramirez, E., and de Ruiz, H. P. (1978). Part trisomy 5p. Human Genetics, 43, 231-237.

Yunis, E., Silva, R., and Giraldo, A. (1976). Trisomy 10p Annales de Génétique, 19, 57-60.

Zabel, B., and Baumann, W. (1977). Trisomie partielle pour la partie distale du bras long du chromosome 15 pद्f translocation X/15 maternelle. Annales de Génétique, 2 \% 285-289.

Zabel, B., Baumann, W., Gehler, J., and Conrad, G. (197\& Partial trisomy for short and long arm of chromosonge no 5. Two cases of two possible syndromes. Journal of Medical Genetics, 15, 143-147.

Zabel, B., Hansen, S., and Hartmann, W. (1976). Partiăt trisomy $2 \mathrm{q}$ and familial translocation $\mathrm{t}(2 ; 12)(\mathrm{q} 31 ; \mathrm{q} 24 \mathrm{~g}$ Human Genetics, 32, 101-104.

Requests for reprints to Professor P. Jalber, Laboratoire de Cytogénétique du CHU de Grenoble Höpital des Sablons, F-38700 La Tronche, France? 